\title{
EVALUATION OF EFFICACY OF THE AMINO ACID-PEPTIDE COMPLEX ADMINISTERED INTRAGASTRICALLY TO GOLDEN HAMSTERS EXPERIMENTALLY INFECTED WITH SARS-COV-2
}

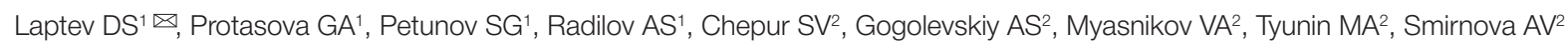

${ }^{1}$ Research Institute of Hygiene, Occupational Pathology and Human Ecology under FMBA, Leningrad region, Russia

${ }^{2}$ State Research and Testing Military Medicine Institute under the Ministry of Defense of the Russian Federation, St. Petersburg, Russia

\begin{abstract}
The development of coronavirus infection outbreak into a pandemic, coupled with the lack of effective COVID-19 therapies, is a challenge for the entire pharmaceutical industry. This study aimed to assess the treatment and preventive efficacy of the amino acid-peptide complex (APC) in male Syrian hamsters infected with SARSCoV-2 (intranasal administration of $26 \mu$ of the virus culture, titer of $\left.4 \times 10^{4} \mathrm{TCD}_{50} / \mathrm{ml}\right)$. In a modeled COVID-19 case, APC administered for treatment and preventive purposes reduced lung damage. Compared to the positive control group, test group had the lung weight factor $15.2 \%$ smaller (trend), which indicates a less pronounced edema. Microscopic examination revealed no alveolar edema, atypical hypertrophied forms of type II alveolocytes, pulmonary parenchyma fibrinization. The macrophage reaction intensified, which is probably a result of the APC-induced activation of regenerative processes in the lung tissues. Spleens of the animals that received APC for therapeutic and preventive purposes were less engorged and had fewer hemorrhages. The decrease of body weight of the test animals that received APC for treatment and prevention was insignificant $(p<0.05)$, which indicates a less severe course of COVID-19. Administered following a purely therapeutic protocol, APC proved ineffective against SARS-CoV-2 post-infection. Thus, APC-based drug used as a therapeutic and preventive agent reduces pulmonary edema and makes morphological signs of lung tissue damage less pronounced in male Syrian hamsters infected with SARS-CoV-2.
\end{abstract}

Keywords: COVID-19, pulmonary edema, atypical pneumocytes, Syrian hamsters

Author contribution: Laptev DS, Protasova GA, Myasnikov VA, Tyunin MA, Smirnova AV — experiment, information collection, data processing; Petunov SG — data processing and interpretation; Radilov AS — scientific concept, consulting; Chepur SV - experiment organization, COVID-19 in vivo model development; Gogolevskiy AS - experiment organization. All authors participated in the manuscript authoring and editing.

Compliance with ethical standards: the study was conducted in conformity to the provisions of the European Convention for the Protection of Vertebrate Animals used for Experimental and other Scientific Purposes.

$\bowtie$ Correspondence should be addressed: Denis S. Laptev

Kapitolovo, str. 93, r.p. Kuzmolovsky, Vsevolozhsky r., 188663; lapden@mail.ru

Received: 21.05.2021 Accepted: 06.06.2021 Published online: 16.06.2021

DOI: $10.47183 /$ mes.2021.011

\section{ОЦЕНКА ЭФФЕКТИВНОСТИ АМИНОКИСЛОТНО-ПЕПТИДНОГО КОМПЛЕКСА ПРИ ВНУТРИЖЕЛУДОЧНОМ ВВЕДЕНИИ ЗОЛОТИСТЫМ ХОМЯКАМ, ЭКСПЕРИМЕНТАЛЬНО ЗАРАЖЕННЫМ SARS-COV-2}

Д. С. Лаптев ${ }^{1}$, Г. А. Протасова', С. Г. Петунов ${ }^{1}$, А. С. Радилов ${ }^{1}$, С. В. Чепур², А. С. Гоголевский², В. А. Мясников², М. А. Тюнин², А. В. Смирнова²

${ }^{1}$ Научно-исследовательский институт гигиены, профпатологии и экологии человека Федерального медико-биологического агентства, Ленинградская область, Россия

2 Государственный научно-исследовательский испытательный институт военной медицины Министерства обороны, Санкт-Петербург, Россия

Распространение коронавирусной инфекции до масштабов мировой пандемии и отсутствие эффективных средств патогенетической терапии COVID-19 являются вызовом для всей фармакологической отрасли. Целью данной работы было оценить эффективность лечебно-профилактического применения аминокислотно-пептидного комплекса (АПК) на самцах сирийских хомяков, подвергнутых заражению SARS-CoV-2 интраназальным введением 26 мкл культуры вируса титром 4 × 104 ТЦД $/$ Мл. Лечебно-профилактическое применение АПК позволяет снизить поражение легких при моделировании COVID-19. Меньший, по сравнению с группой положительного контроля, на 15,2\% (тенденция) весовой коэффициент легких свидетельствует о менее выраженном их отеке. Результаты микроскопического исследования показали отсутствие альвеолярного отека, атипичных гипертросированных форм альвеолоцитов II типа, фибринизации легочной паренхимы. Отмечено усиление макрофагальной реакции, которое, вероятно, является отражением активации АПК регенераторных процессов в тканях легких. В селезенке животных, получавших АПК в лечебно-профилактических целях, выявлена меньшая степень гиперемии с участками кровоизлияний. Отсутствие статистически значимой ( $<<0,05)$ отрицательной динамики массы тела при лечебнопрофилактическом применении AПК отражает снижение общей тяжести течения заболевания COVID-19. Использование AПK по лечебной схеме после заражения SARS-CoV-2 оказалось неэффективным. Таким образом, применение препарата на основе АПК в качестве лечебно-профилактического средства вызывает снижение отека легких и уменьшение морфологических признаков повреждения легочной ткани у самцов сирийских хомяков, подвергнутых заражению SARS-CoV-2.

Ключевые слова: COVID-19, отек легких, атипичные пневмоциты, сирийские хомяки

Вклад авторов: Д. С. Лаптев, Г. А. Протасова, В. А. Мясников, М. А. Тюнин, А. В. Смирнова - экспериментальная часть, сбор информации, обработка данных; С. Г. Петунов - обработка и интерпретация данных; А. С. Радилов - научный замысел, консультирование; С. В. Чепур - организация экспериментальной части работы, разработка in vivo модели COVID-19; А. С. Гоголевский — организация экспериментальной части работы. Все авторы участвовали в подготовке и редактировании рукописи статьи.

Соблюдение этических стандартов: исследование выполняли с соблюдением правил биоэтики, утвержденных Европейской конвенцией о защите позвоночных животных, используемых для экспериментальных и других целей.

$\searrow$ Для корреспонденции: Денис Сергеевич Лаптев

ст. Капитолово, корп. 93, г. п. Кузьмоловский, Всеволожский район, 188663; lapden@mail.ru

Статья получена: 21.05.2021 Статья принята к печати: 06.06.2021 Опубликована онлайн: 16.06.2021

DOI: $10.47183 /$ mes.2021.011 
Despite all the quarantine measures taken, at the turn of 20192020 SARS-CoV-2, a coronavirus causing COVID-19, quickly spread through the Chinese provinces first and then all around the world. According to the World Health Organization, by March 2020 coronavirus infection reached proportions of a pandemic.

According to the published literature, the "gateway" for SARS-CoV-2 infection are cells expressing angiotensinconverting enzyme 2 (ACE2) receptors: respiratory tract epithelium, alveolocytes, vascular endothelium, epithelium of the gastrointestinal tract, myocardium and some parts of the central nervous system [1]. The virus replicates in type II alveolocytes, the replication producing a large number of viral particles. Apoptosis of the affected cells disrupts the pulmonary ventilation and perfusion processes, promotes accumulation of fluid in the alveoli and causes diffuse damage thereof [2].

Joint research effort by scientists from many countries yielded successful development of SARS-CoV-2 vaccines [3], which, provided the vaccination campaigns are largescale, will significantly reduce the number of severe and fatal cases. However, the question of development of effective and safe medications preventing COVID-19 progression into lifethreatening forms remains urgent [4]. Current research and development efforts focus on innovative and cost-effective therapies relying on monoclonal antibodies that would reduce the risk of development of COVID-19 complications [5, 6], as well as on the new approaches to suppress the cytokine storm with the help of opioid peptides that inhibit expression of proinflammatory cytokines by immune cells through suppression of translocation of the nuclear factor kappa $B(N F-\kappa B)$ active dimer [7].

Syrian hamster is the most suitable and accessible experimental model that can be used for preclinical assessment of the efficacy of pharmaceutical drugs against respiratory dysfunction that develops as part of COVID-19 course [8]. Infected with SARS-CoV-2, these animals exhibit clinical picture, viral kinetics, histopathological changes and immune responses very similar to those registered in coronavirus patients [9]. During the first week after infection, the animals had pronounced clinical signs of COVID-19. Rapid respiration and weight loss accompanied histopathological changes, from the initial exudative phase of diffuse damage to the alveoli and extensive apoptosis to a later proliferative phase of tissue repair. There was also registered spleen atrophy, which is probably associated with pronounced activation of cytokines [10].

Since the main causes of death in COVID-19 cases are pulmonary edema, pneumonia and respiratory failure resulting from the virus affecting alveolar cells in the lung's respiratory parts, it seems appropriate to conduct a preclinical study of the drug based on the amino acid-peptide complex (APC) that proved to have an anti-edema effect in an ex vivo pilot study involving isolated rat lungs. The protective effect manifested in slower (1.5 times) increase of the isolated lung-heart complex mass in the test group compared to the control group $(p<0.05)$, the rate measured during 90-minute perfusion, which reflects the rate and degree of development of pulmonary edema [11].

Thus, the purpose of this work was to assess the efficacy of application of the experimental APC for therapeutic and therapeutic and preventive purposes in the male Syrian hamster COVID-19 model.

\section{METHODS}

SARS-CoV-2 was isolated from a clinical sample obtained from a sick patient. The oropharyngeal swab was collected into a $15 \mathrm{~mm}$ tube with DMEM medium (Lonza; Switzerland) without serum and transported to the laboratory. The sample was filtered through a $0.2 \mu \mathrm{m}$ syringe filter on the same day. The virus was isolated and accumulated on a Vero (B) cell culture (BiolT; Russia) in EMEM medium with L-glutasin (BiolT; Russia) with $2 \%$ of fetal bovine serum (BiolT; Russia) and $1 \%$ of antibiotic-antimycotics (Gibco; USA). After each passage employing the real-time polymerase chain reaction reverse transcription method (RT-PCR-RT), we determined the presence of the virus and its titer growth against the original sample with the help of the commercially available Detection Kit for 2019 Novel Coronavirus (2019-nCoV) RNA (PCRFluorescence Probing) (Sun Yat-sen University; China). Having analyzed the virus nucleotide sequence, we established it belonged to GR subclass. The infectious activity of SARSCoV-2 was determined on a Vero (B) cell culture in 96-well plates; the tissue culture infective dose (TCID) was established with the help of the Reed-Muench method [12]. The animals were infected with viral culture of the fifth passage, the titer of which was $4 \times 10^{4} \mathrm{TCD}_{50} / \mathrm{ml}$. The virus was introduced intranasally, with a mechanical Eppendorf dispenser, $13 \mu \mathrm{L}$ into each nostril followed by a controlled inhale.

The test animals were outbred male golden Syrian hamsters Mesocricetus auratus aged 4-6 weeks (body weight of 80-100 g), obtained from the nursery of ZAO NPO Dom farmacii (St. Petersburg). The animals were kept in conditions prescribed by the Directive 2010/63/EU of the European Parliament and of the Council of the European Union of September 22, 2010 (on protection of animals used for scientific purposes) [13]. The controlled parameters were room microclimate (temperature, humidity, air exchange rate), quality of feed and bedding material. The animals were on a standard diet; the feed was formed into pellets. As for the lighting, 12 hours were daytime and 12 hours nighttime.

After randomization by body weight, the animals were divided into four experimental groups $(n=10)$.

Group 1, negative control: daily intragastric (i/g) administration of $\mathrm{APC}$, dose $-75 \mathrm{mg} / \mathrm{kg}$, duration -7 days.

Group 2, positive control: single administration of SARS-CoV-2.

Group 3, treatment and prevention protocol: daily intragastric (i/g) administration of APC, dose $-75 \mathrm{mg} / \mathrm{kg}$, duration -7 days; eighth day of the experiment - infection of the animals with SARS-CoV-2.

Table 1. Body weight of Syrian hamsters infected with SARS-CoV-2; absolute and relative data presented as $M \pm$ SE $(n=10)$

\begin{tabular}{|c|c|c|c|}
\hline Group № & Experiment pattern & Background, $\mathrm{g}$ & $\begin{array}{c}\text { On the } 7^{\text {th }} \text { day after infection, } \mathrm{g} \\
7^{\text {th }} \text { day after infection, } \%\end{array}$ \\
\hline 1 & APC & $105.1 \pm 3.5$ & $101.3 \pm 3.9$ \\
\hline 2 & SARS-CoV-2 & $105.4 \pm 2.6$ & $95.0 \pm 2.7^{\#}$ \\
\hline 3 & $\begin{array}{c}\text { SARS-CoV-2 + APC, treatment } \\
\text { and prevention protocol }\end{array}$ & $106.1 \pm 2.9$ & $98.6 \pm 2.6$ \\
\hline 4 & SARS-CoV-2 + APC, treatment protocol & $107.6 \pm 4.6$ & $93.0 \pm 1.1^{*}$ \\
\hline
\end{tabular}

Note: ${ }^{\#}$ — statistically significant difference from the background; * — statistically significant difference from group 1. 
Table 2. Mass ratios of internal organs of Syrian hamsters infected with SARS-CoV-2 (M \pm SE; $n=10)$

\begin{tabular}{|c|c|c|c|}
\hline Group № & Experiment pattern & Lung mass ratio & Spleen mass ratio \\
\hline 1 & APC & $6.6 \pm 0.1$ & $1.6 \pm 0.1$ \\
\hline 2 & SARS-CoV-2 & $10.5 \pm 0.6^{*}$ & $1.7 \pm 0.1$ \\
\hline 3 & $\begin{array}{c}\text { SARS-CoV-2 + APC, treatment } \\
\text { and prevention protocol }\end{array}$ & $8.9 \pm 0.6^{*}$ & $1.4 \pm 0.1^{\#}$ \\
\hline 4 & SARS-CoV-2 + APC, treatment protocol & $9.5 \pm 0.5^{*}$ & $1.5 \pm 0.2$ \\
\hline
\end{tabular}

Note: * — statistically significant difference from group 1; \# — statistically significant difference from group 2.

Group 4, treatment protocol: infection of hamsters with SARS-CoV-2 followed by APC administration in the course of 7 days.

After the infection with SARS-CoV-2, the animals were observed twice a day for signs of COVID-19 (ruffled fur, hunched posture, shortness of breath, anorexia, lethargy) [14]. Body weights were recorded once a day through the study period.

On the eighth day after infection with SARS-CoV-2, all animals were euthanized by an overdose of general anesthetic (Xila, $20.0 \mathrm{mg} / \mathrm{ml}$ and Zoletil 100, $50.0 \mathrm{mg} / \mathrm{ml}, 1: 1$ ratio, 1.0 $\mathrm{ml}$ per $1.0 \mathrm{~kg}$ of body weight, intramuscularly). Subsequently, their internal organs (lungs, heart, spleen) were taken out for the purposes of assessing the mass ratio (the ratio of the mass of the organ (mg) to the total mass (g)) and pathomorphological analysis.

The internal organs were fixed in formalin (10\%). Tissue-Tek VIP closed cycle histology processor (Sakura; Japan) enabled organ dehydration and degreasing, and Tissue-Tek TEC paraffin station (Sakura; Japan) was used to embedded them in paraffin. The fixed sections $5 \mu \mathrm{m}$ thick were made with the help of Accu-Cut SRM 200 rotary microtome (Sakura; Japan). Histological sections were stained with hematoxylin and eosin, picrofuchsin for connective tissue (Van Gieson's stain), Weigert's elastic stain for fibrin. The nucleic acids were identified with pyronine and methyl green stains (Brachet method). The prepared histological sections were analyzed with the help of Axioskop 40 microscope (Carl Zeiss; Germany) with a ProgRes CFscan color digital camera (Carl Zeiss; Germany) relying on special software to video document the results obtained.

GraphPad Prism 5.04 software (GraphPad Software; USA) enabled statistical processing. With the data distribution among the paired samples being normal, comparison relied on the Student's $t$-test. When the distribution of data was different from normal, the Wilcoxon test for paired samples was used. The intergroup differences were assessed with

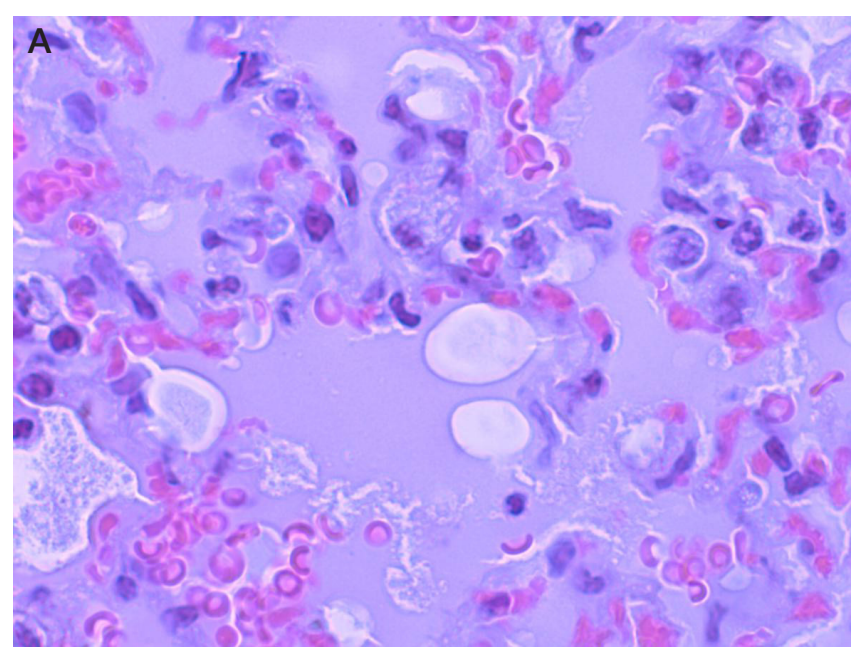

the Mann-Whitney $U$ test. The differences were considered significant at $p \leq 0.05$.

\section{RESULTS}

The experiment established that animals of groups 2 and 4 , which were infected with SARS-CoV-2, statistically significantly lose body weight compared to the animals of the control group 1 (Table 1). The reduction of weight of the group 3 animals, which received APC under the treatment and prevention protocol, was not statistically significant.

All experimental groups had the lung mass ratio increasing to values significantly greater than those registered in the negative control group (APC), but in group 3 (treatment and prevention protocol) this increase was the least pronounced (Table 2). In addition, group 3 animals had their spleen mass ratio decreased significantly.

Pathomorphological analysis of the lungs of group 1 animals revealed a few areas of alveolar hemorrhage and atelectasis in three samples out of five. In addition, it was established that perivascular infiltrates were of predominantly lymphocytic composition. The changes were regarded as spontaneous pathology caused by euthanasia.

Microscopic examination of lung parenchyma revealed that all test animals of group 2 had diffuse alveolar lesions manifested by intra-alveolar edema with an admixture of erythrocytes, macrophages, desquamated damaged alveocytes, lymphocytes (Fig. 1A) and alveolar hemorrhages. Vascular lesions were characterized by thrombosis, perivascular edema and polymorphic cell infiltrates, plasmatization of interalveolar septa and walls of small vessels (Fig. 1B). Also among the findings were hyperplasia and hypertrophy of type II alveolocytes, with pneumocytes of atypical irregular shape and enlarged nuclei and nucleoli (Fig. 2A). Brachet staining allowed a clearer visualization of atypical forms of alveolocytes (Fig. 2B).

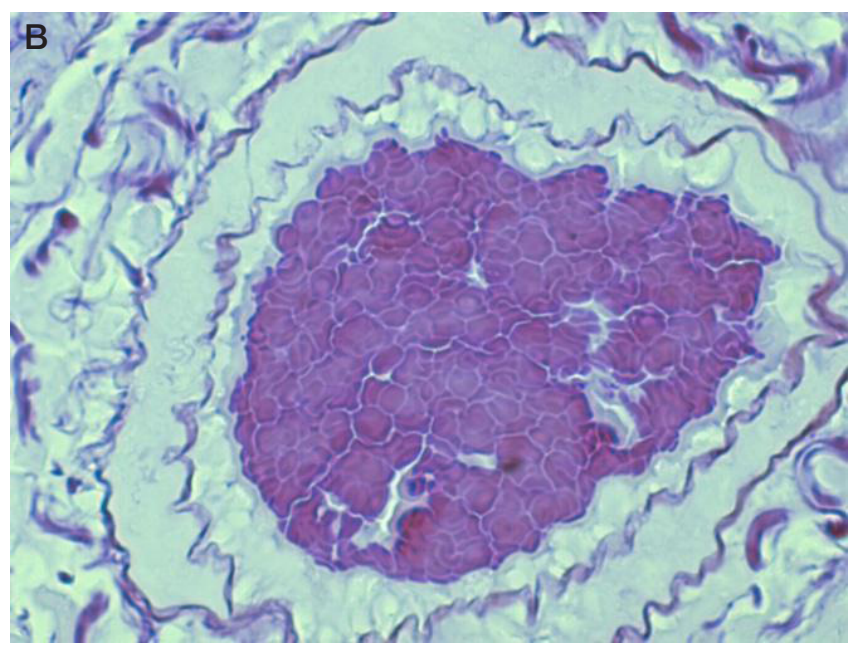

Fig. 1. Lung. Group 2. A. Alveolar edema (stained with hematoxylin and eosin; magnification $\times 1000)$. B. Thrombosis (weigert staining for fibrin; magnification $\times 650$ ) 

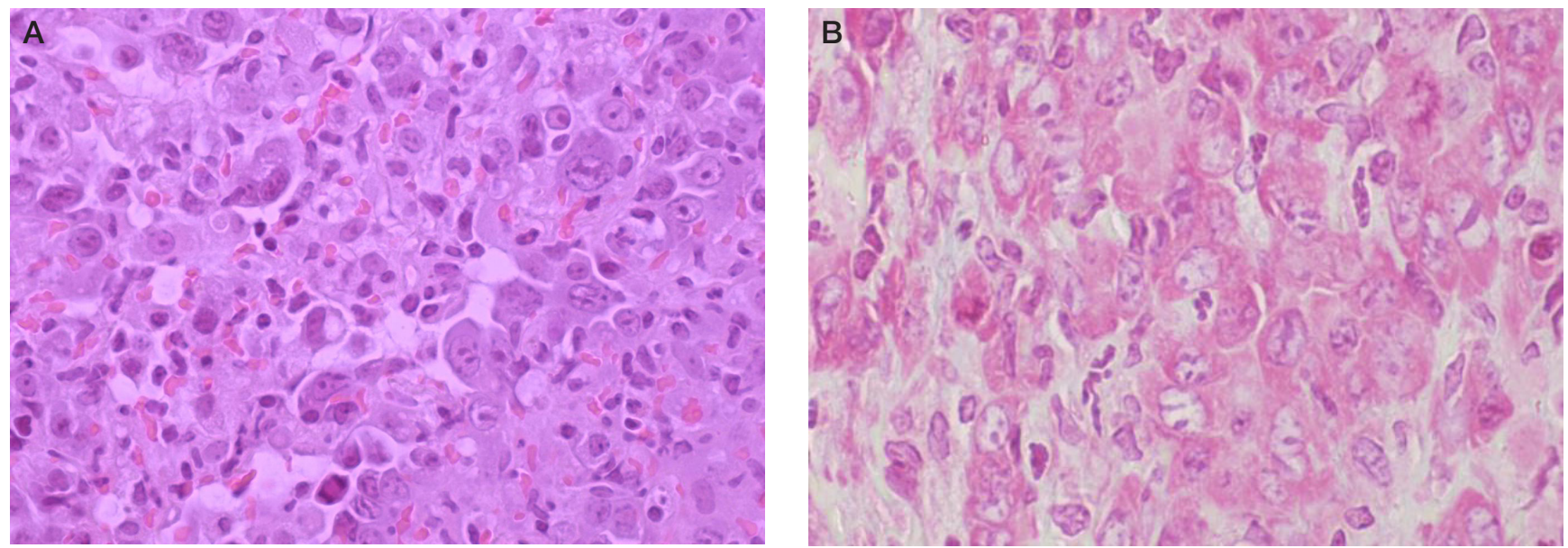

Fig. 2. Lung. Group 2. A. Diffuse alveolar damage, hypertrophied atypical type II alveolocytes (hematoxylin and eosin staining; magnification $\times 650$ ). B. RNA of the cytoplasm of atypical type II alveolocytes stained pink-red, Brachet staining (pyronine and methyl green; magnification $\times 1000$ )

In two test animals of group 2 the lungs had fibroblast proliferation foci with developing tissue granulation. The fibrin in lung parenchyma (discovered with Weigert stain) was diffused (Fig. 3A, B).

In group 3 (treatment and prevention protocol), four our of five animals had their pathomorphological picture characterized by the absence of alveolar pulmonary edema. Microscopy of the lungs revealed peribronchial and perivascular infiltrates, areas of microbleeds in the lung parenchyma (three out of five animals). In addition, hyperplasia of type II alveolocytes
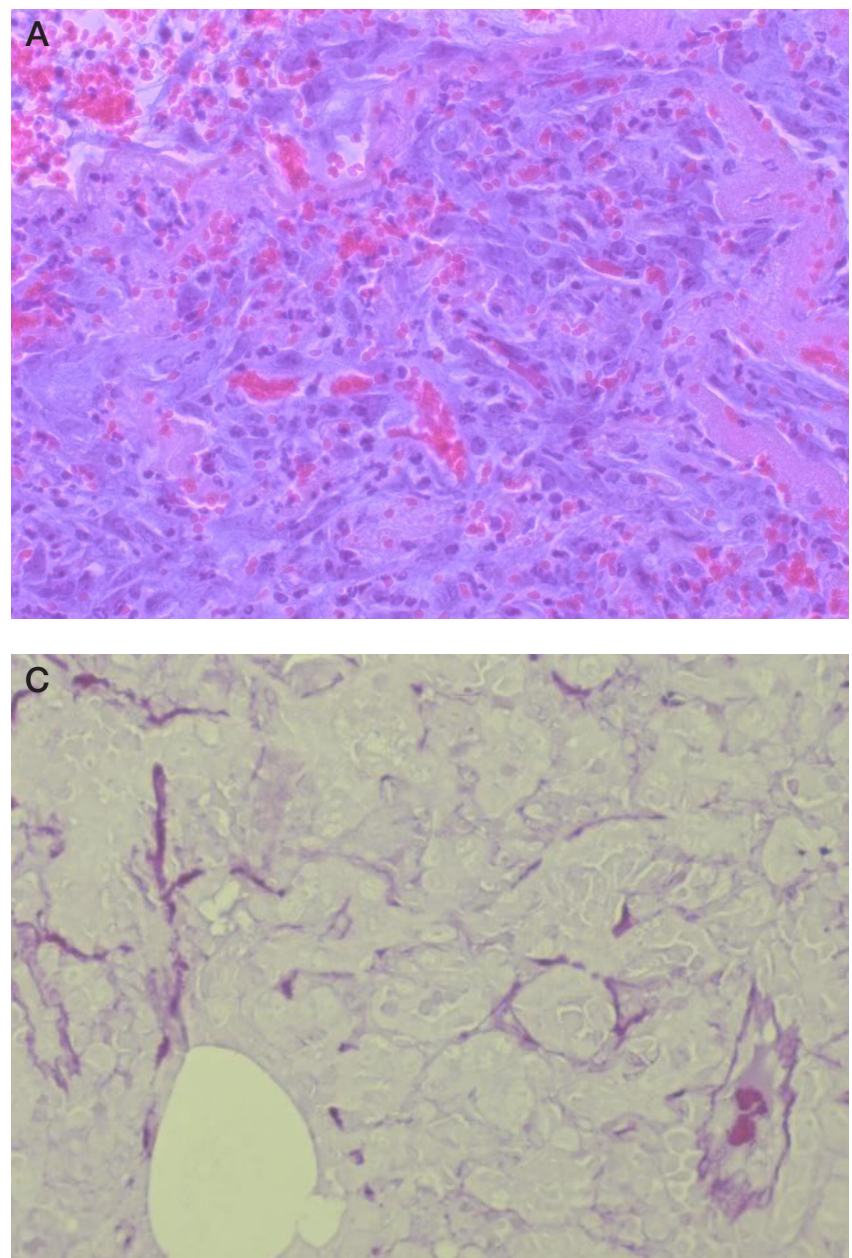

and an increase in macrophage reaction were registered (Fig. 4A, B). Alveolocyte hypertrophy and atypia were observed in only one of five animals. In this group, Weigert staining of lung preparations did not reveal fibrinization of the parenchyma (see Fig. 3D).

Pathomorphological changes in the lungs of group 4 animals were largely the same as the destructive changes in the lung parenchyma of group 2 animals.

The analysis of histological preparations of the heart did not reveal any morphological differences between test groups, with
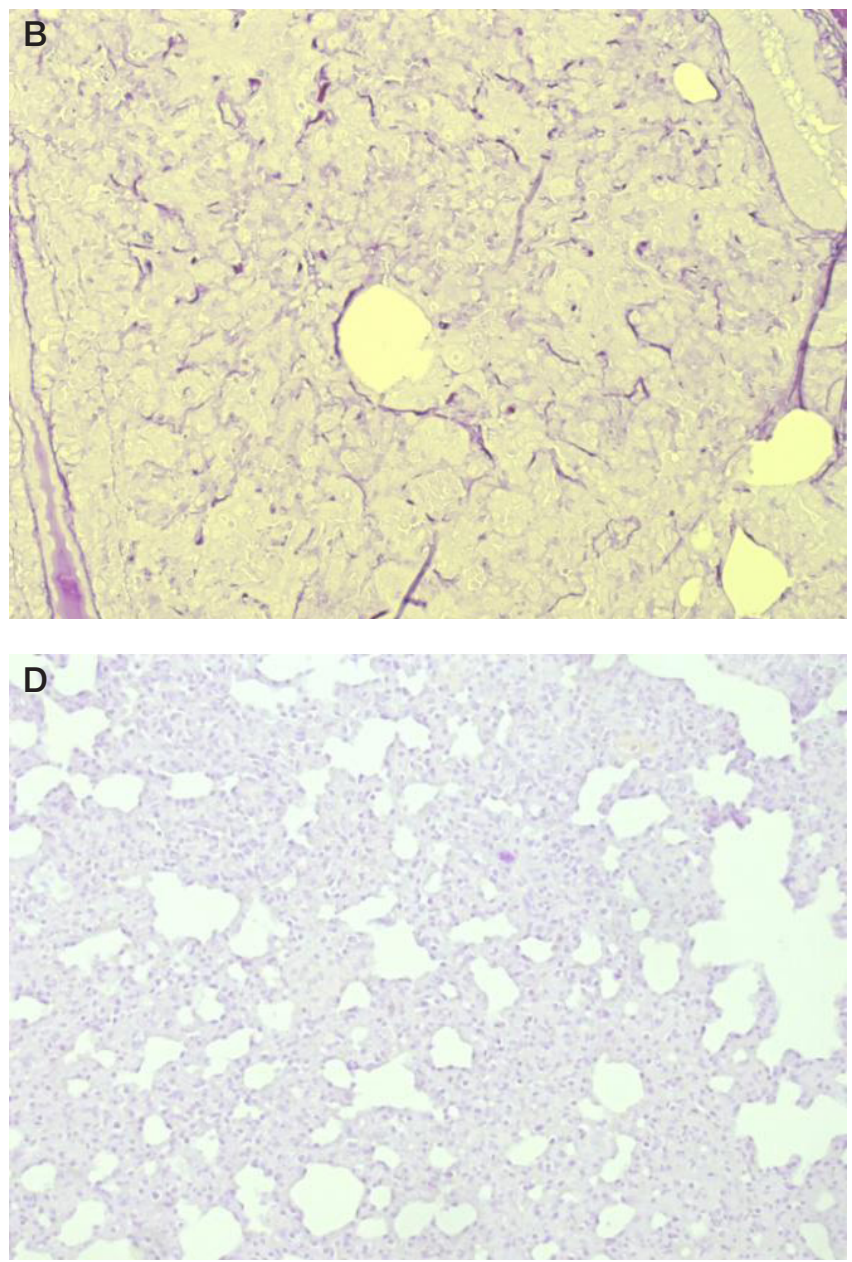

Fig. 3. Lung. Group 2. A. Fibroblast proliferation, focal fibrosis, hemorrhage (staining with hematoxylin and eosin; magnification $\times 400)$. B. Diffuse deposition of fibrin in the parenchyma (magnification $\times 200$ ). C. Fibrin deposits in lung parenchyma (magnification $\times 400$ ). D. Group 3, no fibrin (weigert staining for fibrin; magnification $\times 200$ ) 

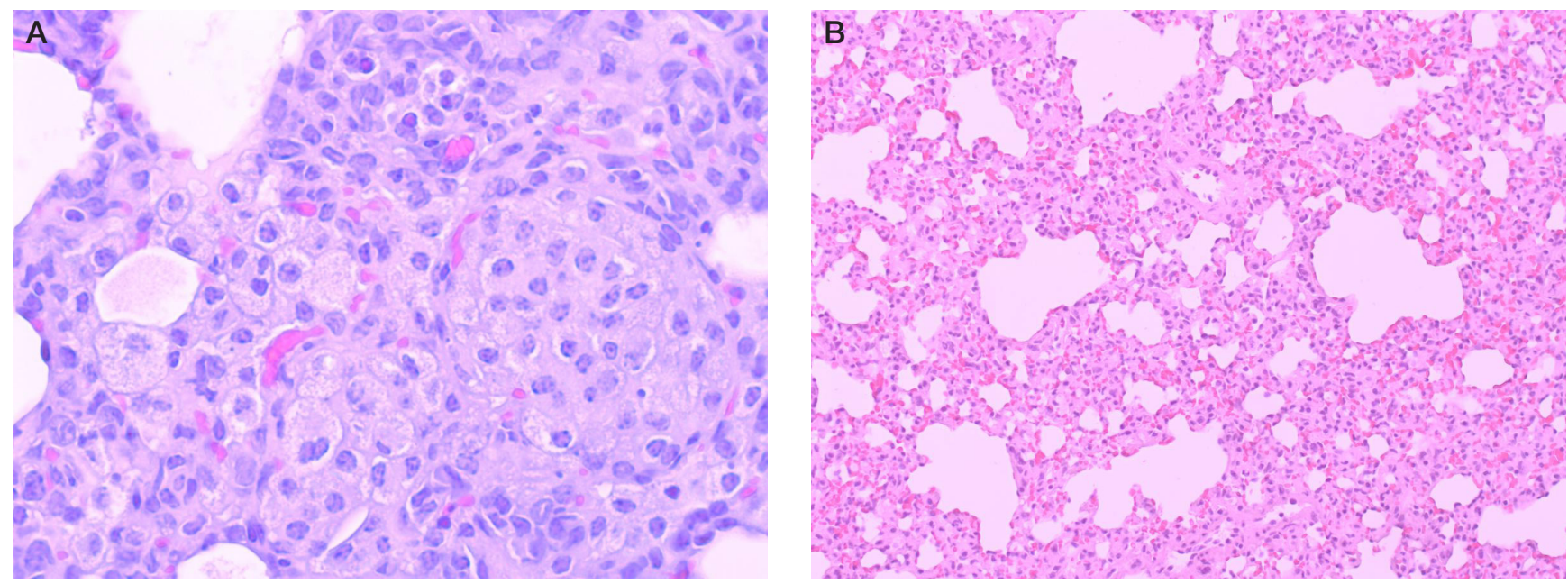

Fig. 4. Lung. Group 3. A. Polymorphic-cell infiltration, reinforced macrophageal response (magnification $\times 650$ ). B. No diffuse alveolar damage in the lungs (staining with hematoxylin and eosin; magnification $\times 200$ )

the exception of two animals, one from group 1 (control), which had pericarditis, and one from group 4, which had pericarditis, myocarditis, spot necrosis and hemorrhage.

Microscopic examination of the spleen revealed that the follicular structures of the white pulp and reactive centers were not changed, and the level of mitosis was same as with the control. In the red pulp of the spleen, there was an accumulation of plasmacytic cells of varying maturity; the degree of severity differed within groups (in two out of five animals in groups 1, 2 and 3 , in three out of five animals in group 4). Plasmacytic cells were detected by histochemical staining with methyl green and pyronine (the Brachet method). In addition, hyperemia with hemorrhage was observed in all groups, with the most pronounced changes registered in groups 2 and 4 .

\section{DISCUSSION}

According to our observations, administration of the APCbased medication to Syrian hamsters under the treatment and prevention protocol makes the course of the disease less severe, the alleviation manifesting in smaller weight loss, which is considered an integral indicator characterizing general condition of the body infected with SARS-CoV-2. The body weight loss trend observed in hamsters receiving APC is probably connected with its stimulating effect on energy metabolism and activation of catabolic processes [15].

The lung mass ratio decrease shows that the edema grows less pronounced, which confirms the previous assumption of the studied drug's decongestant effect revealed on the isolated lungs model [11]. This effect may be the result of the APCbased medication's ability to limit permeability of the bloodair barrier through support of the cells' metabolism by active components of the drug and regulation of the glucose uptake by direct translocation of the GLUT family transporters to plasma membrane, which makes the medication a promising remedy for mitochondrial dysfunction [15].

Pathomorphological examination of the lungs showed that a single intranasal administration of $26 \mu \mathrm{l}$ SARS-CoV-2 solution (virus titer $4 \times 10^{4} \mathrm{TCD}_{50} / \mathrm{ml}$ ) triggered COVID-19 in
Syrian hamsters, the disease manifesting in diffuse alveolar lung damage with vascular lesions, which associates with its early exudative stage [16].

Pathomorphological analysis allowed determining the main criteria for evaluation of the lung preparations: presence of alveolar edema, intraalveolar hemorrhages, hyperplasia, hypertrophy and atypia of type II alveolocytes, proliferation of fibroblasts, lung parenchyma vascular lesions (perivascular edema, infiltrates), thrombi, etc.

The comparative pathomorphological evaluation of the lungs of SARS-CoV-2-infected animals that received APCbased drug under the treatment and prevention protocol (group 3) and group 2 animals (positive control) revealed certain differences in histopathological changes. Group 3 animals had no alveolar edema, atypical and hypertrophied forms of type II alveolocytes, lung parenchyma fibrinization. All animals of this group exhibited reinforced macrophage response, which, most likely, reflects activation of regenerative processes in the lungs.

Pathomorphological analysis of histological preparations of lungs, heart and spleen of group 4 animals (received APCbased drug under the treatment protocol) revealed pulmonary edema, hemorrhages, hypertrophy and atypia of alveolocytes, vascular damage. The nature of the destructive changes identified generally corresponded to that found in group 2 animals.

Administration of the APC under the treatment protocol did not have a significant effect on the course of the infectious process. The established fact corresponds to the literature data on the greater effectiveness of certain pharmacological agents when they are used for COVID-19 prevention rather than therapy, which may be associated with the virulence of SARS-CoV-2, its high replication rate and rapid development of clinical manifestations of the disease $[17,18]$.

\section{CONCLUSIONS}

APC-based drug used as a therapeutic and preventive agent reduces pulmonary edema and makes morphological signs of lung tissue damage less pronounced in male Syrian hamsters infected with SARS-CoV-2. 
1. Zhou P, Yang XL, Wang XG, Hu B, Zhang L, Zhang W. A pneumonia outbreak associated with a new coronavirus of probable bat origin. Nature. 2020; 579: 270-73.

2. Kogan EA, Berezovskij YuS, Procenko DD, Bagdasarjan TR, Grecov EM, Demura SA, i dr. Patologicheskaja anatomija infekcii, vyzvannoj SARS-COV-2. Cudebnaja medicina. 2020; 2: 8-30. Russian.

3. Heinz FX, Stiasny K. Profiles of current COVID-19 vaccines. Wien Klin Wochenschr. 2021; 1-13. DOI: 10.1007/s00508-02101835-w.

4. DeFrancesco L. COVID-19 antibodies on trial. Nat Biotechnol. 2020; 38: 1242-52. DOI: 10.1038/s41587-021-00813-x.

5. Brouwer JM, Caniels TG, Straten K, Snitselaar JL, Aldon $Y$, Bangaru S, et al. Potent neutralizing antibodies from COVID-19 patients define multiple targets of vulnerability. Science. 2020; 369: $643-50$

6. Tortorici A, Beltramello M, Lempp FA, Pinto D, Dang HV, Rosen LE. Ultrapotent human antibodies protect against SARS-CoV-2 challenge via multiple mechanisms. Science. 2020; 370: 950-7. DOI: 10.1126/science.abe3354.

7. Karkischenko VN, Pomytkin IA, Skvortsova VI. The Opioidergic System of Immune Cells: A New Pharmacological Target in the Therapy of "Cytokine Storm". Journal Biomed. 2020; 16 (4): 14 23. Russian.

8. Sia SF, Yan LM, Chin AH, Fung K, Choy KT, Wong AL, et al. Pathogenesis and transmission of SARSCoV-2 in golden hamsters. Nature. 2020; 583 (7818): 834-8. DOI: 10.1038/ s41586-020-2342-5.

9. Imaia M, Iwatsuki-Horimotoa K, Hattab M, Loeberc S, Halfmannb PJ. Syrian hamsters as a small animal model for SARS-CoV-2 infection and countermeasure development. PNAS. 2020; 117 (28): 16587-95. DOI: 10.1073/pnas.2009799117.

10. Chan JF, Zhang AJ, Yuan S, Poon VK, Chan CC, Lee AC, et al. Simulation of the clinical and pathological manifestations of Coronavirus Disease 2019 (COVID-19) in golden Syrian hamster model: implications for disease pathogenesis and transmissibility. Clin Infect Dis. 2020; 71 (9): 2428-46. DOI: 10.1093/cid/ciaa325.

11. LaptevDS, Petunov SG, Nechaykina OV, Bobkov DV, RadilovAS. Using experimental ex vivo models to develop COVID-19 pathogenetic therapy and complications prevention agents. Extreme Medicine. 2020; (4): 6-12. DOI: 10.47183/mes.2020.020. Russian.

12. Reed LJ, Muench $\mathrm{H}$. A simple method of estimating fifty percent endpoints. Am J Hygiene. 1938; 27: 493-7.

13. Rybakova AV, Makarova MN. Sanitarnyj kontrol' jeksperimental'nyh klinik (vivariev) v sootvetstvii s lokal'nymi i mezhdunarodnymi trebovanijami. Mezhdunarodnyj vestnik veterinarii. 2015; 4: 8189. Russian.

14. Nambulli S, Xiang Y, Tilston-Lunel NL, Rennick LJ, Sang Z, Klimstra WB, et al. Inhalable Nanobody (PiN-21) prevents and treats SARS-CoV-2 infections in Syrian hamsters at ultra-low doses. Sci Adv. 2021; 7 (22): eabh0319. DOI: 10.1126/sciadv. abh0319.

15. Barnes $\mathrm{K}$, Ingram JC, Porras $\mathrm{OH}$, Barros LF, Hudson ER, Fryer LG, et al. Activation of GLUT1 by metabolic and osmotic stress: potential involve ment of AMP activated protein kinase. J Cell Sci. 2002; 115: 2433-42.

16. Zabozlaev FG, Kravchenko YeV, Galljamova AR, Letunovskij NN. Patologicheskaja anatomija legkih pri novoj koronavirusnoj infekcii (SOVID-19). Predvaritel'nyj analiz autopsijnyh issledovanij. Klinicheskaja praktika. 2020; 11 (2): 60-76. Russian.

17. Baum BA, Ajithdoss D, Copin R, Zhou A, Lanza K, Negron N, et al. REGN-CoV2 antibodies prevent and treat SARS-CoV-2 infection in rhesus macaques and hamsters. Science. 2020; 370: 1110-5.

18. Hartman AL, Nambulli S, McMillen CM, White AG, TilstonLunel NL, Albe JR, et al. SARS-CoV-2 infection of African green monkeys results in mild respiratory disease discernible by PET/ CT imaging and shedding of infectious virus from both respiratory and gastrointestinal tracts. PLoS Pathog. 2020; 16 (9): e1008903. DOI: 10.1371/journal.ppat.1008903.

\section{Литература}

1. Zhou P, Yang XL, Wang XG, Hu B, Zhang L, Zhang W. A pneumonia outbreak associated with a new coronavirus of probable bat origin. Nature. 2020; 579: 270-73.

2. Коган Е. А., Березовский Ю. С., Проценко Д. Д., Багдасарян Т. Р. Грецов Е. М., Демура С. А. и др. Патологическая анатомия инфекции, вызванной SARS-COV-2. Судебная медицина. 2020; 2: 8-30.

3. Heinz FX. Stiasny K. Profiles of current COVID-19 vaccines. Wien Klin Wochenschr. 2021; 1-13. DOI: 10.1007/s00508-02101835-w.

4. DeFrancesco L. COVID-19 antibodies on trial. Nat Biotechnol. 2020; 38: 1242-52. DOI: 10.1038/s41587-021-00813-x.

5. Brouwer JM, Caniels TG, Straten K, Snitselaar JL, Aldon $Y$, Bangaru S, et al. Potent neutralizing antibodies from COVID-19 patients define multiple targets of vulnerability. Science. 2020; 369: $643-50$

6. Tortorici A, Beltramello M, Lempp FA, Pinto D, Dang HV, Rosen LE Ultrapotent human antibodies protect against SARS-CoV-2 challenge via multiple mechanisms. Science. 2020; 370: 950-7. DOI: 10.1126/science.abe3354.

7. Каркищено В. Н., Помыткин И. А., Скворцова В. И. Опиоидэргическая система иммунных клеток: новая фармакологическая мишень в терапии «цитокинового шторма». Биомедицина. 2020; 16 (4): 14-23.

8. Sia SF, Yan LM, Chin AH, Fung K, Choy KT, Wong AL, et al. Pathogenesis and transmission of SARSCoV-2 in golden hamsters. Nature. 2020; 583 (7818): 834-8. DOI: 10.1038/ s41586-020-2342-5.

9. Imaia M, Iwatsuki-Horimotoa K, Hattab M, Loeberc S, Halfmannb PJ. Syrian hamsters as a small animal model for SARS-CoV-2 infection and countermeasure development. PNAS. 2020; 117
(28): 16587-95. DOI: 10.1073/pnas.2009799117.

10. Chan JF, Zhang AJ, Yuan S, Poon VK, Chan CC, Lee AC, et al. Simulation of the clinical and pathological manifestations of Coronavirus Disease 2019 (COVID-19) in golden Syrian hamster model: implications for disease pathogenesis and transmissibility. Clin Infect Dis. 2020; 71 (9): 2428-46. DOI: 10.1093/cid/ciaa325.

11. Лаптев Д. С., Петунов С. Г., Нечайкина О. В., Бобков Д. В., Радилов А. С. Использование экспериментальных моделей ex vivo для разработки средств патогенетической терапии и профилактики осложнений COVID-19. Медицина экстремальных ситуаций. 2020; 22 (4): 6-13. DOI: 10.47183/mes.2020.020.

12. Reed LJ, Muench $\mathrm{H}$. A simple method of estimating fifty percent endpoints. Am J Hygiene. 1938; 27: 493-7.

13. Рыбакова А. В., Макарова М. Н. Санитарный контроль экспериментальных клиник (вивариев) в соответствии с локальными и международными требованиями. Международный вестник ветеринарии. 2015; 4: 81-89.

14. Nambulli S, Xiang Y, Tilston-Lunel NL, Rennick LJ, Sang Z, Klimstra WB, et al. Inhalable Nanobody (PiN-21) prevents and treats SARS-CoV-2 infections in Syrian hamsters at ultra-low doses. Sci Adv. 2021; 7 (22): eabh0319. DOI: 10.1126/sciadv. abh0319.

15. Barnes K, Ingram JC, Porras $\mathrm{OH}$, Barros LF, Hudson ER, Fryer LG, et al. Activation of GLUT1 by metabolic and osmotic stress: potential involve ment of AMP activated protein kinase. J Cell Sci. 2002; 115: 2433-42.

16. Забозлаев Ф. Г., Кравченко Э. В., Галлямова А. Р., Летуновский Н. Н. Патологическая анатомия легких при новой коронавирусной инфекции (COVID-19). Предварительный анализ аутопсийных исследований. Клиническая практика. 2020; 11 (2): 60-76. 
17. Baum BA, Ajithdoss D, Copin R, Zhou A, Lanza K, Negron N, et al. REGN-CoV2 antibodies prevent and treat SARS-CoV-2 infection in rhesus macaques and hamsters. Science. 2020; 370: 1110-5.

18. Hartman AL, Nambulli S, McMillen CM, White AG, Tilston-
Lunel NL, Albe JR, et al. SARS-CoV-2 infection of African green monkeys results in mild respiratory disease discernible by PET/ CT imaging and shedding of infectious virus from both respiratory and gastrointestinal tracts. PLoS Pathog. 2020; 16 (9): e1008903. DOI: 10.1371/journal.ppat.1008903. 